\title{
The Cost of Gender Equity: Title IX at the University of Oregon
}

\section{Lauren Goss*, Department of History}

\begin{abstract}
Title IX of the Education Amendments of 1972 prohibits discrimination on the basis of sex at any educational institution that receives federal funding. Intended to focus on unfair admission practices, Title IX became known for mandating equal treatment (facilities, uniforms, coaching) for female intercollegiate athletes. The intricacies of implementing these federal standards presented substantial challenges, and universities confronted the ideological intersection of equality and autonomy in different ways. The University of Oregon administration remedied overtly discriminatory policies, most notably in facility access, but acute inequities persisted. Becky Sisley, the first and only Director of Women's Intercollegiate Athletics for the University of Oregon, served as the driving force for changing athletic policies for women athletes in the 1960s and 1970s. Archival evidence and extensive oral interviews corroborate this struggle for adequate funding, coaching, and recognition. The Women's Intercollegiate Association (WIA) survived on a meager budget, but routinely competed in national competitions. The organization remained autonomous until 1977, when the University of Oregon combined the WIA and the Athletic Department. The loss of leadership in the merger, and Sisley's resignation shortly thereafter, hindered any further attempts to reach true equality. The implementation of Title IX at the University of Oregon created a paradox for women's athletics: an expansion of equality for female athletes, but a decline in autonomy for coaches and administrators of women's athletics.
\end{abstract}

\section{INTRODUCTION}

Title IX of the Education Amendments of 1972 serves as a litmus test for gender equality in education. Commonly associated with controversy in intercollegiate athletics, the law states:

*Lauren Goss graduated from the Robert D. Clark Honors College at the University of Oregon in 2011 with a degree in History. She is currently working at a law firm in Portland and is in the process of applying to graduate programs in Museum Studies. Please send correspondence to Goss.lauren@gmail.com. 
No person in the United States shall, on the basis of sex, be excluded from participation in, be denied the benefits of, or be subjected to discrimination under any education program or activity receiving Federal financial assistance. ${ }^{1}$

Implementation of the law forced colleges and universities to overhaul their athletic programs. Amidst the consequences associated with Title IX, the University of Oregon followed the national trend of combining men's and women's athletic departments as a streamlining and cost saving measure. Despite miniscule budgets during its existence, the Women's Intercollegiate Association (WIA), a member of the Association of Intercollegiate Athletics for Women (AIAW), experienced significant growth and development under the leadership of the University of Oregon Director of WIA, Becky Sisley. Teams routinely had winning seasons, attended national championships, and represented the University of Oregon with great pride. In fact, in 1975, Sisley noted in an article in the Register-Guard, the University of Oregon was the "only school in the country which sent girls to every national meet last fall." ${ }^{1}$ Despite this success, the Athletic Department took over the WIA in 1977. While Title IX brought notable and equitable gains in funding, scholarships, recruiting, and coaching staff, and increased the recognition of female athletics at the University of Oregon, the involuntary absorption of the women's program into the Athletic Department hindered further growth of the program by a female leader and reinforced pervasive gender stereotypes regarding female athletes.

\section{PERCEPTION OF WOMEN IN SPORT AT THE UNIVERSITY OF OREGON}

Reflected in popular culture, the University of Oregon media perpetuated gender specific stereotypes regarding female athletes. Once thought to be damaging to the female reproductive system, fitness and recreation were finally socially acceptable endeavors for women. In the 1960s, "the American Medical Association, which had warned for years that strenuous competition might be harmful to girls, finally reversed itself and recommended more vigorous activity." ${ }^{2}$ Beyond the ability to compete in sports, many women wanted recognition for their efforts. An article in the Oregon Daily Emerald about the women's gymnastics team in 1973 opened with a line encapsulating the knowledge and attitude of the general student body: "Women's collegiate sports get next to no publicity, little funding and small fan support."3 The article profiled two women gymnasts preparing for a regional championship to be held at the University of Oregon. Despite the high level of competition displayed by the gymnastics team, the team members expressed disappointment. Jeanine Navarra, the author of the article, implored the reader to understand the position of the athletes: "Men don't give women athletes much recognition and Linda feels it's probably because "they don't know we exist." 4 This illustrative statement by gymnast Linda Stuber highlighted the campus attitude about female athletes stemming from institutional and societal inequities against women's intercollegiate athletics.

The University of Oregon volleyball team also suffered from low public interest. In an article that appeared in the Register-Guard in October of 1978, the opening line once again set the precedent: "It's rare that the University of Oregon volleyball team can draw as many as 350 fans 
and have most of them on their feet cheering at the end of just the first game." 5 Attendance at women's sports events at the University of Oregon was considered to be non-important. Thus, the University of Oregon media portrayal of female student-athletes was commensurate with the public's opinion and beliefs. Title IX focused on ending gender discrimination perpetuated through inequitable intercollegiate athletics.

\section{TITLE IX}

Title IX of the Education Amendments of 1972 specifically prohibited discrimination on the basis of sex at any educational institution receiving federal funds. Presented in the United States House of Representatives by Rep. Edith Green (D-OR), the law aimed to equalize educational opportunities for both sexes. Explaining the importance of this law, Green stated that at the time, "it was perfectly legal to discriminate in any education program against girls or women."6 This landmark legislation effectively restructured several policies and procedures at schools across the United States: counseling, admissions, housing, and employment, to name a few. Striking changes occurred at the intercollegiate athletic level. Eventually the law affected several areas: the structure of the athletic department, funding, facilities, marketing, scholarships and the number of teams and athletes.

After the passage of Title IX on June 23, 1972, universities were unsure about the real impact of the legislation. The ambiguity of the text necessitated governmental clarification about how and to what extent the law would be applied in athletics. Therefore, from 1974 to 1975, the Department of Health, Education and Welfare (HEW) drafted and finalized "Regulations on Nondiscrimination on the Basis of Sex." In a subsection titled "Equal opportunity," ten areas were enumerated:

1. Whether the selection of sports and levels of competition effectively accommodate the interests and abilities of members of both sexes;

2. The provision of equipment and supplies;

3. Scheduling of games and practice time;

4. Travel and per diem allowance;

5. Opportunity to receive coaching and academic tutoring;

6. Assignment and compensation of coaches and tutors;

7. Provision of locker rooms, practice and competitive facilities;

8. Provision of medical and training facilities and services;

9. Provision of housing and dining facilities and services;

10. Publicity 7 
These areas of examination, commonly referred to as the "shopping list" or "laundry list," served as a rubric to identify inequities on university campuses across the nation.

Initially, the University of Oregon administration and Athletic Department viewed Title IX with anxiety. Reflected in a 1974 Oregon Daily Emerald article entitled, "HEW requires equal programs: Varsity football women?" the author noted, "men's and women's teams would have equal access to sports facilities as well as equivalent coaching staff and travel needs." 8 This article was written after HEW drafted preliminary regulations for public review. A few weeks later, another article offered a view on how the law may affect the University of Oregon. David Frohnmayer, the special assistant for legal affairs to the President of the University, pressed for more discussion regarding the law. Frohnmayer said, "in the area of intercollegiate athletics, implementation of the guidelines will force a fundamental rethinking of some basic but conflicting social values." 9 These "conflicting social values" caused havoc in the eventual merger of the Athletic Department with the Women's Intercollegiate Association. Controversy commonly occurred and continues to persist when schools try to incorporate total equality for their male and female sports programs. However, "Title IX does not require equal spending. The law required equitable accommodations." ${ }^{10}$ This idea of "equitable accommodations" framed the rubric that the University of Oregon Title IX Task Force (1975-76) used in its self-evaluation report.

\section{SELF-EVALUATION OF INEQUITABLE PRACTICES}

The implementation of Title IX required several steps at the University of Oregon, including a systematic self-evaluation conducted in $1975-76$ by University of Oregon faculty, administrators, sports directors and students. The most numerous inequities were found in intercollegiate athletics. Required by HEW, the self-evaluation aimed to, "evaluate in terms of sex discrimination its current policies and practices...modify any policies or practices which do not meet the requirements of the Title IX regulation; and take whatever remedial actions necessary to eliminate the effects of past sex discrimination." 11 The report was due by July 21, 1976. The self-evaluation was the first step towards compliance, mandatory by July 21, 1978. This document provided the best snapshot of the status of women athletes at the University of Oregon during the 1970s.

Overall, the University of Oregon lacked equitable practices in the realm of women's athletics. Not unlike many other universities, the programs for women paled in several areas when compared to men's athletics. The results of this self-evaluation report were made public and were reported in the Oregon Daily Emerald. The evaluation examined several campus areas, including the athletic "shopping list," and provided recommendations for identifiable gender equity issues. The report found that "of the 85 recommendations made by the committee, 38 concerned the physical education and athletic departments." 12 The 38 recommendations only concerned improvements for women's athletics. In summation, the report focused on "an increased number of athletic facilities for women, a larger staff of coaches and personnel for women's sports and a scholarship program for women athletes." 13 Progress was achieved in these three areas as a result of the merger of the previously gendered athletic 
programs in 1977. Accommodating these changes forced administrators and coaches to address additional issues of equity between the women's and men's programs.

\section{PUBLICITY}

Budget constraints limited the ability of the WIA to promote and advertise their sports. The Title IX Task Force Committee found disparities in the area of publicity between the men's athletics and women's athletics programs, most notably in the communications with potential high school students:

The women's program annually distributes a flyer in which both general and specific information about the entire Women's Intercollegiate Athletic program is contained. The men's athletic department does not disseminate a general descriptive publication; instead, coaches of individual intercollegiate sports in the men's program annually send out letters to prospective student athletes. ${ }^{14}$

The Task Force recommended that "all publications...contain a statement which makes reference to the fact that opportunities for participation in intercollegiate athletics programs are available to both men and women at the University." 15 Publicity was important to gaining new athletes from high schools; however, it was not necessary in order to find great talent. Peg Rees, the last female athlete to compete in three sports (volleyball, basketball and softball) for the University of Oregon, did not know the WIA existed when she came to school in 1973 as a freshman:

It was New Student Week freshman year; I was walking from the area of the library towards the dorms. School hadn't started. Karla Rice, the volleyball coach, for some reason was standing in a doorway of Gerlinger when I walked by, and I am 5' 10”, which for my era was pretty tall, and she said-it was probably about 3 in the afternoon- 'Do you play volleyball?' I said yes, which was kind of a lie. I had played in P.E., which was 9 on $9 . .$. but I had never competed in it. And she said 'We have a team here on campus and we are meeting at 5 o'clock tonight' and she encouraged me to come. ${ }^{16}$

While Rees' story is inspiring, informal recruiting was not a sustainable practice. As a result of Title IX and the self-evaluation report, in 1975 the athletic department created "a sports information director post in the news bureau that [would] handle both men's and women's sports publicity."17 Developments such as these were precursors to a combined department. A major part of publicity was the opportunity to hold events where spectators could enjoy the game. Even more important was the name recognition and accessibility of certain venues, such as McArthur Court, commonly referred to as Mac Court.

\section{FACILITIES}

Due to HEW-mandated regulations and the self-evaluation report, WIA benefited from a more equitable distribution and use of facilities. The Title IX Task Force recommended that "facilities should be scheduled so that 'key' or 'popular' or 'convenient' times for practice or 
competition are divided equally between men and women."18 The University of Oregon first allowed the women's basketball and volleyball teams to use McArthur Court in 1977. Previously, those teams practiced and competed in the gym in the basement of Gerlinger Annex. The softball team practiced on the small field behind the library and competed at Amazon Park. Other women's sports used rooms in Gerlinger Gym and the Annex. The University of Oregon, like many other universities, in order "to meet the need for more facilities for the expanded women's program," 19 allowed for previously male-only facilities to be used by both sexes. Consequently, the recognition and health of the female athletes greatly benefited from Title IX.

In an appendix to the Title IX Task Force Report, two University of Oregon female athletes testified during a public hearing about the dangerous conditions they faced in substandard facilities. The women addressed the danger level of certain facilities:

According to two students, the women's basketball floor is constructed of wood over a cement base, a composition which has resulted in jammed knees, sprained ankles, and shin splints, and which has required knee surgery for at least five students. The softball practice field, located next to the library, is also dangerous, according to the two students, because of ditches in the ground caused by application of lime to the field during band practices. ${ }^{20}$

In addition to the questionable conditions of the gym in Gerlinger Annex and the softball practice field, the women's field hockey team encountered poor field conditions. The field hockey team practiced on the field between University Street, the cemetery, Gerlinger Annex, and Gerlinger Gym. The team competed in games at South Eugene High School. In a field hockey scrapbook documenting the team from 1973-1977, a full-page spread with pictures documented the dangerous conditions of the field. The unknown author wrote:

After a lot of griping about the unsafe condition of our practice field, something was done to try and remove the 'hills.' Practice was moved inside while work was done. The grass was taken up, small sections at a time. Dirt was then put in to try and level out the ground. The grass was put back in on top of the new dirt. ${ }^{21}$

While the conditions of Gerlinger Field slightly improved, Title IX enabled the team to use other facilities. On some occasions, the field hockey team hosted their home matches in Autzen Stadium. Diane Smith, a varsity field hockey player from 1972 to 1976, noted:

I remember how cool it was to actually get to play some games at Autzen Stadium, and how much different it was to not have the mud to contend with, to not have to splash around in the mud, and of course the difference between the Astroturf and the grass at that time. That seemed like a big deal to be able to all of a sudden be playing a couple of games at Autzen. ${ }^{22}$

This memory signifies the changes occurring in women's athletics. More importantly, it implies just how novel it was for women to play where the men played. 
Despite the equalization in facilities usage, the new procedures were met with frustration from male athletes and coaches. In an article in the Oregon Daily Emerald, a reporter noted the resentment against women getting to use the facilities. Going against the status quo was an obstacle because, "when boys have had virtually all of the money and facilities, sharing will be difficult,' said Dr. Norma Raffel of the Women's Equity Action League.”23 In 1977, the women's and men's track and field teams competed in the first dual meet ever at Hayward Field. Men's coach Bill Dellinger expressed anxiety about the length of the meet. Dellinger "was concerned that [the meet] would stretch...as long as five hours. He feels that would be a kiss of death for dual meets in Eugene, which he thinks became so popular partly due to the fact former Coach Bill Bowerman insisted they be run off in less than three hours." 24 In addition to facilities, Title IX also mandated equal funding, which was vital given the enormous funding disparity at the University of Oregon.

\section{BUDGET}

A large portion of the research surrounding Title IX implementation at universities focuses on the budgets of women's athletic programs. Allen Guttman, author of Women's Sports: A History, bluntly stated, "That the inequalities between men's and women's programs were obscenely gross is undeniable." ${ }^{25}$ In addition to anecdotal evidence, Guttman also introduced quantitative data. "The average expenditure on women's sports for the NCAA's Division I was \$27,000 in 1973-74 and \$400,000 in 1981-82." ${ }^{26}$ William Brook examined AIAW institutions in his thesis, "Assessing the impact of Title IX and other factors on women's intercollegiate athletic programs, 1972-1977: a national study of four-year AIAW institutions." In his statistical analysis, he found "forty-three colleges (of 219) were funded above $\$ 8$,00o in 1972-73 while 168 colleges received budgets which exceeded that amount in 1976-77." ${ }^{27}$ This analysis of total budget does not include salaries. The increase in budgets resulted from pressures to comply with Title IX.

Similar studies described the budget disparities at the University of Oregon. For the 19761977 season, the WIA's "budget was one-thirteenth the size of the men's athletic department."28 The 1975-1976 budget for the WIA calculated to one-seventeenth, therefore the budget improved, however minuscule the progress. The following table identifies increases in the WIA budget. The full-time employment (FTE) statistic is of note. A full-time employee receives a value of 1.00, a half-time employee receives a rating of .50. Therefore, the FTE data reflected the prevalence of GTF coaches and other coaches doubling up their duties.

Table 1: Data Reflecting Effects of Title IX on Women's Athletic Program, Prepared 12/8/78.

\begin{tabular}{|l|l|l|l|}
\hline & $1976-77$ & $1977-78$ & $1978-79$ \\
\hline Total Budget & $\$ 186,128$ & $\$ 248,583$ & $\begin{array}{l}\$ 424,598 \\
\text { (excludes trainer or } \\
\text { other support } \\
\text { services) }\end{array}$ \\
\hline
\end{tabular}




\begin{tabular}{|l|l|l|l|}
\hline $\begin{array}{l}\text { Scholarship } \\
\text { Allocation } \\
\text { (incl. reserves and } \\
\text { contingencies) }\end{array}$ & $-\$ 0-$ & $\$ 11,340$ & $\$ 73,878$ \\
\hline $\begin{array}{l}\text { Total FTE (full time } \\
\text { equivalent) }\end{array}$ & 6.3 & 7.96 & 9.98 \\
(incl. 1.6 trainers) & (incl. 1.45 trainers) & (no trainers) \\
\hline $\begin{array}{l}\text { Increase from } \\
\text { previous year }\end{array}$ & $\$ 31,850$ & 1.63 & 2.02 \\
\hline $\begin{array}{l}\text { Team Travel } \\
\text { Support }\end{array}$ & $(>\$ 582$ less) & $(\$ 10,930)$ & $\$ 78,200$ \\
\hline $\begin{array}{l}\text { Increase from } \\
\text { Previous Year }\end{array}$ & $\$ 42,780$ & $\begin{array}{l}\text { (major increase in } \\
\text { per diem allowance) }\end{array}$ \\
\hline $\begin{array}{l}\text { National } \\
\text { Championship } \\
\text { Allocation }\end{array}$ & $\$ 29,600$ & $\$ 21,400$ & $\$ 50,000$ \\
\hline
\end{tabular}

Source: Data from University of Oregon Department of Intercollegiate Athletics: Data Reflecting Affects of Title IX on Women's Athletic Program, Women's Athletics, UA 029, Special Collections \& University Archives, University of Oregon Libraries, Eugene, Oregon.

Women's athletics, part of the Physical Education Department, received funding from the Incidental Fee Commission (IFC) and from the University of Oregon administration. Throughout the 1970s, the IFC and Associated Students of the University of Oregon (ASUO) determined the budget of the WIA. In addition to program fees and coaches' salaries, the WIA had to forecast the number of teams to attend nationals and all of the associated costs. The forecast was not always correct. Peg Rees recalled a time when the volleyball team had qualified for nationals, but the WIA did not have adequate contingency funding to send the team. ${ }^{29}$ The program relied on IFC funds, but budget proposals did not always produce good results. Earlier in 1975 , the commission proposed to give significantly less money, only $\$ 20,000$, when the WIA asked for $\$ 198,000.3^{30}$ The vote was eventually overturned. However, as women's athletics gained prominence and asked for more money, Athletic Department administrators raised concerns about finding new funding sources.

Nationally, Title IX produced fear about how to appropriate new funds for the women's programs without "sacrificing” men's athletics. In 1975, an article in the Oregon Daily Emerald about facilities usage documented the anxiety: "college coaches and athletics directors have vigorously opposed the new rules on grounds they will kill off athletics for men if already scarce funds must be shared for women's programs." ${ }^{31}$ This fear was present at the University of 
Oregon and several ideas to increase overall funding were shared. The most prominent, and the biggest failure for increased funding, was a 1977 legislative bill for state financial aid. Athletic Director John Caine said he was "...doubtful they c[ould] come up with funds equal to the nearly $\$ 1$ million the bill would have provided." 32 the bill's failure forced the university administration to explore other alternatives, such as cutting both male and female non-revenue sports.

\section{SCHOLARSHIPS AND RECRUITING}

Title IX provoked philosophical disparities at the University of Oregon regarding scholarships and recruiting. The AIAW believed first and foremost that a collegiate athlete was a student. In 1973, the AIAW produced a white paper regarding scholarships and recruiting. On the matter of the value of sports, AIAW members explained, "programs in an educational setting should have these objectives as primary goals. Political, economic, or entertainment goals may be positive in nature, but may also obliterate the intrinsic reasons for participation." 33 When scholarships were first administered to female athletes at the University of Oregon, they were grants-in-aid. Sisley explained that "national guidelines specif[ied] that only tuition scholarships c[ould] be given to women athletes, while schools [were] allowed to include room, board and books as well for men." 34 The differences in scholarships between the AIAW and the NCAA would prove to be an obstacle for Title IX compliance at the University of Oregon.

Women athletes did not primarily attend universities based on their athletic ability, a tenet of female sports that AIAW administrators wished to maintain. Sisley pointed out that scholarships were not necessary for success: "We have had good performances in the past without scholarships,' recalling that Oregon sent all of their women's teams-except basketballto national finals" in 1976." 35 Nevertheless, in discussions about scholarships, the University of Oregon Committee on Intercollegiate Athletics reached a consensus in 1974 to allow scholarships for female athletes. Some salient points were raised regarding the principles behind these awards. Russ Pate, a doctoral candidate in exercise physiology in 1974 and co-coach for the women's track and field team strove to define "the purpose for scholarships [a]s for individual aid, not for the purpose of producing winning teams." ${ }^{6} 6$ The committee reached a similar consensus: "to consider first priority as need, second priority academic and athletic ability." ${ }^{37}$ In contrast, coaches gave male athletes full-ride scholarships based on athletic talent as confirmed during recruiting trips.

In addition to resistance towards scholarships, female coaches initially avoided recruiting. In 1978, the University of Oregon women's volleyball coach, Chris Voelz, remarked, "'Other schools may be ahead in recruiting,' but she was interested more in the athletes individually. 'Our intent is not to buy bodies, but to award achievement,' she claimed." ${ }^{8}$ Similar policies existed in women's athletics at other universities in Oregon. At Portland State: "I'm not in favor of buying athletes," declared Dr. Marlene Piper, "all the buying and hustling is not part of a college education and I hope we in the women's field can keep that element out of it." 39 The pressure to recruit based on athletic talent distracted players from academics and coaches from the enrichment of the student-athlete. However, because Title IX required equality, women's sports conformed to the pre-existing male model. Beginning in the 1980s, "women [on a national scale] 
were more likely to have chosen their school because of its sports program, and . . that increasingly professionalized sports participation tended to diminish their commitment to the classroom." 40 The waning emphasis on education was exactly the direction administrators of women's athletics wanted to avoid.

\section{PRIORITIES OF A STUDENT ATHLETE}

The AIAW and WIA emphasized skill and education rather than entertainment. In the previously mentioned article about the gymnastics team, the author noted, tellingly, "unlike male team sports, women gymnasts don't have a crowd cheering them on, or a captain calling the shots, or anyone to blame for making a wrong move. All they have is their skill, training and experience." ${ }^{11}$ Athletic talent aside, education was of utmost importance. In an article from the Oregon Daily Emerald, Sisley said, "I am a professional educator. And I'm not going to alums for money and be dragged into the win-or-else trap." 42 Similarly, Chris Voelz, the varsity volleyball coach, wrote a "Competitor Contract" for each of her athletes to sign. One of the provisions stated: "a conscientious competitor is also a conscientious student." 43 The WIA viewed education as the top priority of a University of Oregon female athlete.

The focus on education by coaches of women's sports was represented at the national level. William Brooke's thesis, "Assessing the impact of Title IX and other factors on women's intercollegiate athletic programs, 1972-1977: a national study of four-year AIAW institutions," confirmed this argument. He collected data from 219 schools out of the total 689 AIAW schools at the time. One area he surveyed examined "Male/Female Directors Compared on Philosophy of Athletics." He provided choices: "Business or entertainment," "Education," "Both," and "Other." From his results, he concluded, "for 1972-73, the female director-coordinators favored the characterization 'Education' by 77.7 percent, while 11.5 percent selected 'Both.” 44 Brooke resurveyed the schools and discovered "for 1976-77, the percentage of women who selected 'Educational' decreased by 17.5 percent while those who selected 'Both' increased 21.6 percent." 45 In an interview with the Oregon Daily Emerald, Becky Sisley clarified the priorities of her program:

Whereas some men's sports-besides being an educational experience for the athletesemphasize entertainment and produce revenue, WIA emphasized an educational experience with no intent to entertain to produce revenue. Our emphasis is on providing a quality competitive program within a sound educational framework. When we go on trips we attempt to mingle with our opponents and to learn about the area. 46

As the two University of Oregon athletic programs merged in 1977, concerns were raised about reconciling the priorities of male and female student-athletes and their coaches.

\section{COEDUCATIONAL ATHLETIC DEPARTMENT}

The 1977 merging of the Athletic Department and the Women's Intercollegiate Association, prompted by a drive to streamline staffing and an effort to be Title IX compliant, led to the 
dissolution of power and leadership for the WIA. The discussion of a coeducational athletic department began in earnest in 1973. The idea began with a proposal to the University StudentFaculty Committee on Intercollegiate Athletics by a student named Jane Aiken. She argued that, "the present system of separate athletic departments for men and women is partly responsible for student hostility toward funding the Athletic Department with student incidental fees...The formation of a single athletic department would help athletics in general at the University." 47 The meeting prompted considerable discussion amongst the members. "Wendell Basye, professor of law, noted that at the Pacific-8 Conference meeting he attended in December, 'everybody had started talking about women's problems in intercollegiate athletics.' Basye said funding is the main problem facing women's athletics." 48 The committee continued to work on the proposal through 1973. Vice President of Finance and Administration Ray Hawk heavily pushed for the merger as a way to comply with Title IX. In 1975, when the Task Force Committee began their deliberations, he said, "I'm sure a consolidated athletic department will eventually be established...It's inevitable." 49 Furthermore, he clarified who would be the leader of the Athletic Department: "the new athletic director 'could conceivably be a woman' but finding a woman with the necessary experience in the business and promotion of big box-office athletic competition 'isn't very likely." ${ }^{0}$ The rhetoric chosen for Hawk's justification, with obtuse reference to "big box-office competition," is in direct contrast with the sports philosophy of women expressed at the local and national level. At the campus level, the new athletic director, John Caine, in 1976 responded to merger criticism: "I'd like to make it clear that we are all for women's athletics at Oregon. We just don't want it to ruin men's athletics." ${ }^{11}$ The choice of a man to oversee the entire athletic department caused concern for the future of women's athletics.

The WIA faced this inevitable and irrevocable change with strong resistance. In 1975 Sisley identified a conflict of ideology: “our major concern in combining [with the Athletic Department] is whether the women would still have a voice in the running of their programs. The men's programs are off on such a different tangent that we'd like to keep them separate." ${ }^{2}$ However, after the 1977 merger, the male athletic director and the director of intercollegiate athletics would be one in the same. As a result, Sisley became the Director of Women's Intercollegiate Athletics, but now had to pass items by John Caine and Ray Hawk. In retrospect, Becky Sisley remarked, "it goes back to this philosophy difference and the rules differences. That is what Title IX created, this huge dilemma that you have to follow the same policies and procedures. So what do you do? You've got to do what the men do."53 The combination of the two philosophies of sport brought much frustration for female athletes who were now judged based on the male model. Women continued to be marginalized even in the name of progress and equality.

The merging of athletic departments occurred nationwide in the 1970s. In Brooke's analysis of AIAW universities, he discovered, "of the 211 colleges that supplied data for this problem area, 54.5 percent, or 115 colleges, had combined the two programs under one athletic department by 1976-77. Only 49 colleges had reported such a merger in 1972-73." 54 Though the majority of schools combined the two programs, controversies remained. Brooke also provided 
additional analysis about the attitude towards merging at the campus level and the national governance level. An overwhelming " 84.6 percent of the female director-coordinators wished to retain governance of their programs under the AIAW while 45.7 percent of the male directorcoordinators preferred that the AIAW adopt the guiding principles of the men's organizations while retaining governance." 55 In spite of documented resistance, combined athletic departments became a standard practice.

\section{CONCLUSION}

Undeniably, Title IX brought changes to University of Oregon women's athletics. Budgets increased, facilities usage equalized, and publicity improved. Overall, Title IX increased gender equity to standards never seen before. However, the changes were not as progressive as some had originally hoped. In 1976, Becky Sisley said in regards to Title IX progress, "I won't say substantial [progress], but there have been changes." ${ }^{6}{ }^{6}$ The underlying sentiments of Sisley, Rees and Smith, as expressed in their interviews, can be summed up in this way: "although Title IX has forced changes, it has not wrought miracles." ${ }^{57}$ In 1980, another self-evaluation examined the progress of gender equity. Many problems had not been taken care of, and simple items were still left to accomplish. Examining the changes that occurred between 1972 and 1977, the work done from 1977 to 1980 left a lot to be desired.

The plateau of gender equity in athletics at the University of Oregon was a direct result of the merger. While student-athletes enjoyed new amenities, female coaches lost autonomy and the power to uphold the tenets of female athletics. The presence of a leading voice for women's athletics slowly dissolved into the male-dominated department. When Becky Sisley retired in 1979, her replacement, Julie Carson, became known as the "Deputy Director of Intercollegiate Athletics." The previous title "Director of Women's Intercollegiate Athletics" ceased to exist. The athletic department literally subsumed the women's program, and the women lost administrative independence. The work completed by the AIAW and the WIA to establish a new way of approaching athletics, namely focusing on the education of the student, fell away to accommodate big box office demands and alumni expectations. The ironic results of Title IX at the University of Oregon, as well as across the country, perpetuate the paradox of opportunity and discrimination for female student-athletes.

\section{ACKNOWLEDGEMENTS}

I must acknowledge the work of former University Archivist Heather Briston for her foresight to collect and preserve women's intercollegiate athletic history. Secondly, I admire the eagerness and generosity of my oral interviewees to share their memories. Every female studentathlete builds upon the foundations of previous athletes, and their contributions to gender equity remain priceless. Thirdly, I must acknowledge the guidance provided by my thesis committee: Professor Ellen Herman, Professor Kevin Hatfield, and Professor Samantha Hopkins. Thank you to my loved ones for being marvelous role models and providing unceasing support. A final acknowledgement is essential to all of the University of Oregon female student- 
athletes, including my mother, who in the face of considerable odds proudly represented their school in intercollegiate athletics.

\section{BIBLIOGRAPHY}

1973 Field Hockey, Field Hockey Scrapbook 1973-1977, UA 029, Special Collections \& University Archives, University of Oregon Libraries, Eugene, Oregon.

A.I.A.W. White Paper on Women's Sports, Women's Athletics, UA 029, Special Collections \& University Archives, University of Oregon Libraries, Eugene, Oregon.

Blumenthal, Karen. Let Me Play: The Story of Title IX: The Law that Changed the Future of Girls in America. New York: Atheneum Books for Young Readers, 2005.

Brooke, William O. "Assessing the impact of Title IX and other factors on women's intercollegiate athletic programs, 1972-1977: a national study of four-year AIAW institutions." Thesis (doctoral), Arizona State University, 1979.

Brown, Becky. "IFC recommends no funds for WIA." Oregon Daily Emerald, April 17, 1975.

Competitor Contract, University of Oregon Volleyball 1978, Women's Athletics, UA 029, Special Collections \& University Archives, University of Oregon Libraries, Eugene, Oregon.

Conrad, John. “Oregon will try the coed way.” Register-Guard, March 31, 1977.

Don, Mary. "HEW requires equal programs: Varsity football women?” Oregon Daily Emerald, June 25, 1974.

Eggers, Kerry. “Strict HEW rules ease upon football.” Oregonian, December 7, 1978.

Federal Register, Volume 40, Number 108 (June 4, 1975), 24142-43.

Guttmann, Allen. Women’s Sports: A History. New York: Columbia University Press, 1991.

Henkel, Cathy. "Oregon adds a little spice to the spikes.” Register-Guard, October 4, 1978.

Kayfes, Dave. “Oregon's Becky Sisley; Eighty hours a week for women’s athletics.” RegisterGuard, May 3, 1976.

Matthew, Madeleine. "Women get athletic grants in Title IX compliance step." Oregon Daily Emerald, July 12, 1977.

Merriman, Todd. “Coed AD Proposed.” Oregon Daily Emerald, January 9, 1973.

Navarra, Jeanine. "It's lots of work-and no recognition." Oregon Daily Emerald, February 13, 1973. 
Nielson, Jeff. "Women's coach recalls basketball in dark gym.” Oregon Daily Emerald, May 21, 1975.

Open Forum, Department of P.E. June 4, 1974. Faculty Archives: Becky Sisley Papers, 10.016 A (Folder 2), Special Collections \& University Archives, University of Oregon Libraries, Eugene, Oregon.

Pemberton, Cynthia Lee A. More than a Game: One Woman's Fight for Gender Equity in Sport. Boston: Northeastern University Press, 2002.

“Prof urges Title Nine input.” Oregon Daily Emerald, July 2, 1974.

Rees, Peg. Personal Interview. November 5, 2010.

"Report evaluates Title IX compliance: Task force ends seven-month review." Oregon Daily Emerald, July 27, 1976.

Richards, Suzanne. "Women's Sports: Feds Change the Game” Oregon Journal. September 28, 1977.

Sands, Ken. “Netters facing transitional period.” Oregon Daily Emerald, September, 1978.

Sidbury, Anne. “Title IX investigations approach result release.” Oregon Daily Emerald, July 20, 1976.

Sisley, Becky. Personal interview. October 22, 2010.

Smith, Diane. Phone interview. November 12, 2010.

“State blind to Title IX.” Oregon Daily Emerald, July 5, 1977.

Title IX Self Evaluation Final Recommendations. Becky Sisley’s Personal Collection.

University of Oregon Department of Intercollegiate Athletics: Data Reflecting Affects of Title IX on Women's Athletic Program, Women's Athletics, UA 029, Special Collections \& University Archives, University of Oregon Libraries, Eugene, Oregon.

U.S. Code. Title 20, Chapter $38 \S 1681$. Sex.

Van Deusen, Beth. “Title IX: Women's sports renaissance.” Oregon Daily Emerald, February 14, 1975.

Waldstein, Phil. "University task force to investigate Title Nine requirements, propose plans." Oregon Daily Emerald, December 1, 1975.

Welch, Bob. "Women's Sports: Title IX takes effect; no swords drawn.” Oregon Daily Emerald, September 25, 1975 .

“Women to use athletic facilities.” Oregon Daily Emerald, June 26, 1975. 


\section{ENDNOTES}

1 Dave Kayfes, “Oregon's Becky Sisley; Eighty hours a week for women's athletics,” RegisterGuard, May 3, 1976.

2 Karen Blumenthal, Let Me Play: The Story of Title IX : The Law that Changed the Future of Girls in America. (New York: Atheneum Books for Young Readers, 2005), 60.

3 Jeanine Navarra, "It's lots of work-and no recognition," Oregon Daily Emerald, February $13,1973$.

4 Ibid.

5 Cathy Henkel, “Oregon adds a little spice to the spikes,” Register-Guard, October 4, 1978.

6 Blumenthal, Let Me Play: The Story of Title IX : The Law that Changed the Future of Girls in America, 24.

$7 \quad$ Federal Register, Volume 40, Number 108 (June 4, 1975), 24142-43.

8 Mary Don, “HEW requires equal programs: Varsity Football Women?” Oregon Daily Emerald, June 25, 1974.

9 “Prof urges Title Nine Input,” Oregon Daily Emerald, July 2, 1974.

1o Cynthia Lee A. Pemberton, More than a Game: One Woman's Fight for Gender Equity in Sport. (Boston: Northeastern University Press, 2002), 15.

11 Title IX Self Evaluation Final Recommendations. Becky Sisley's Personal Collection. Introduction, 2.

12 "Report evaluates Title IX Compliance: Task force ends seven-month review" Oregon Daily Emerald, July 27, 1976.

13 Ibid.

14 Title IX Self Evaluation Final Recommendations. Becky Sisley's Personal Collection. Publications, 2.

15 Title IX Self Evaluation Final Recommendations. Becky Sisley's Personal Collection. Publications, 3 .

16 Peg Rees, interview by author, Eugene, OR, November 5, 2010.

17 Phil Waldstein, "University task force to investigate Title Nine requirements, propose plans," Oregon Daily Emerald, December 1, 1975. 
18 Title IX Self Evaluation Final Recommendations. Becky Sisley's Personal Collection. Athletics, 2.

19 William O. Brooke, "Assessing the impact of Title IX and other factors on women's intercollegiate athletic programs, 1972-1977: a national study of four-year AIAW institutions." (Thesis (doctoral), Arizona State University, 1979), 105.

Title IX Self Evaluation Final Recommendations. Becky Sisley's Personal Collection. Appendix C: Public Comments, 3 .

211973 Field Hockey, Field Hockey Scrapbook 1973-1977, UA 029, Special Collections \& University Archives, University of Oregon Libraries, Eugene, Oregon. [Hereafter cited as SCUA]

Diane Smith, Telephone Interview, November 12, 2010.

“Women to use athletics facilities,” Oregon Daily Emerald, June 26, 1975. 
36 Open Forum, Department of P.E. June 4, 1974. Faculty Archives: Becky Sisley Papers, 10.016 A (Folder 2), Special Collections \& University Archives, University of Oregon Libraries, Eugene, Oregon.

37 Open Forum, Department of P.E. June 4, 1974. Faculty Archives: Becky Sisley Papers, 10.016 A (Folder 2), SCUA.

38 Ken Sands, “Netters facing transitional period," Oregon Daily Emerald, September, 1978.

39 Richards, "Women's Sports: Feds Change the Game."

40 Guttman, 214.

41 Navarra, "It's lots of work—and no recognition."

42 Beth Van Deusen, “Title IX: Women's sport renaissance,” Oregon Daily Emerald, February 14,1975 .

43 Competitor Contract, University of Oregon Volleyball 1978, Women's Athletics, UA 029, SCUA.

44 Brooke, 93.

$45 \quad$ Ibid., 93.

46 Bob Welch, "Women's Sports: Title IX takes effect; no swords drawn," Oregon Daily Emerald, September 25, 1975.

47 Todd Merriman, “Coed AD Proposed,” Oregon Daily Emerald, January 9, 1973.

48 Ibid.

49 Phil Waldstein, "University task force to investigate Title Nine requirements, propose plans," Oregon Daily Emerald, December 1, 1975.

50 Ibid.

${ }^{51}$ Kerry Eggers, “Strict HEW rules ease upon football,” Oregonian. December 7, 1978.

$5^{2}$ Jeff Nielson, "Women's coach recalls basketball in dark gym," Oregon Daily Emerald, May 21, 1975 .

53 Becky Sisley, interview by author, Eugene, OR, October 22, 2010

54 Brooke, 48.

55 Brooke, iv. 
56 Anne Sidbury, "Title IX investigations approach result release," Oregon Daily Emerald, July $20,1976$.

57 Guttman, 222. 